\title{
THE EFFECT OF REAL MEDIA ON THE STUDENTS' ABILITY IN WRITING PROCEDURE TEXT OF THE EIGHTH YEAR STUDENTS OF SMP SWASTA DEWANTARA PUTRA SEBERTUNG AT ACADEMIC YEAR 2018/2019
}

\author{
Efrini Panjaitan, Eva Riana Silalahi \\ STKIP Budidaya Binjai \\ efrinipanjaitan@gmail.com
}

\begin{abstract}
The study deals with an experimental research design which seeks for the effect of real media on students' ability in writing procedure text. The problems that had been identified by the writer are including many of junior high school students have difficulties in understanding the genres of text, they still get lack of vocabularies which makes the students difficult to compose any kinds of text, the procedural texts seem hard for students to comprehend without any practical media, the written language is more complicated than spoken one, and teacher does not have very effective strategy to overcome the students' inability in learning procedural text. 70 students at the eighth year students at SMP Swasta Dewantara Putra Sebertung in academic year of 2018/2019 are taken as the subject of the study. Multiple choices are used to obtain the data on the variable. The final data then is analyzed by using technique of $t$-test analysis. The result shows that coefficient of $t_{\text {counted }}(3.37)$ was greater than the $t_{\text {table }}$ coefficient (1.66757). This means that there is the effect of real media on students' ability in writing procedure text of the 2018/2019 eighth year students of SMP Swasta Dewantara Putra Sebertung. Therefore, the hypothesis of the study is accepted.

Keywords: Real Media, Procedure Text, Writing Ability
\end{abstract}

\section{INTRODUCTION}

English is an International language, which is used by most people all over the world, taught and learnt in many countries either as second language or foreign language. As an international language, English has gained its popularity all over the world including Indonesia. In Indonesia, English has an important place in the educational curriculum. English is regarded as the first foreign language to be taught at school. In the past, English was only taught in secondary schools as a compulsory subject and as an additional subject at universities. In current years, however, the teaching of English has expanded into elementary school setting as a local content. It means Indonesian government has considered the importance of learning English as an international language. That is why English is taught at school to prepare Indonesian people to participate in the global era.

The fact that has been found in the field when the writer did some observations to the students at SMP Swasta Dewantara Putra Sebertung, that there are many students who have limited understanding about procedure text. It is shown when the writer tries to teach the students about procedural text in the class, the students are too lack to understand not only the generic structure or the linguistic features but also very hard to be persuaded to do a procedural thing like making a simple glass of tea. Even though the text is the simple to 
complex text to be understood and made. From the writer's observation, the students need more time to understand the text and the English teacher gives some examples of text by demonstrating through the concrete materials such as demonstrating how to serve a bowl of fried noodle. Besides, in the academic year of 2018/2019, the average of English achievement of the eighth year students at SMP Swasta Dewantara Putra Sebertung is below the minimum standards of criteria (KKM) scored 65 and $70 \%$ of the students have gained less than the standard score according to the data which the writer has done before the research (pre-research). For this instance, there are three of all the students at class VIII-B named Ganda who was obtaining 64, Alfira was gaining 62 and Jaya was having the bottom score 58 .

Giving the skill and knowledge to the students is teaching learning process. Theoretically, teaching is conveying the science and skill to other people by using a certain strategy. Teaching strategy has an important role in the teaching learning process beside other components such as the purpose, material and methods. Roestiyah states that the teacher must have the strategy to create the study to be effective and efficient, which is based on the expected objective.

The quotation that tells the teacher must use strategy in teaching in order to get the objective of teaching is not interesting for the students. It is better for the teacher to choose a suitable technique to teach the text. According to Grondlund, one of the learning styles is "enjoyable learning". It means that the students have fun in learning and keep the students active and cast off the boredom.

By the reason, strategy is very important to the teacher. The teacher will be unsuccessful in teaching if the teacher does not use one of teaching strategies. Therefore, a teacher has to consider what teaching strategy to use and how to organize the learning environment. So that the students will have experience that helps the students to achieve whatever learning outcomes, and the teacher has identified as desirable as possible. That, the teacher has to choose teaching strategies according to what it is, that the teacher wants the students to be able to do as a result of the teaching.

The media plays a central role in informing the public about what happens in the world, particularly in those areas in which audiences do not possess direct knowledge or experience. This article examines the impact the media has in the construction of public belief and attitudes and its relationship to social change. Drawing on findings from a range of empirical studies, the publics look at the impact of media coverage in areas such as disability, climate change and economic development. 
Ability to express meaning in a simple short monologue using a variety of spoken language accurately, fluently and acceptably in order to interact within the context of everyday life in a given context form of procedure is one of the basic competences that must be mastered by students. In teaching procedure text, the students are asked to read and translate the text. Furthermore, the students are asked to do the exercise based on the procedure text. During the process of learning, the students seem very passive and complaining, and feel insecure. The students have great difficulty in doing these duties. Obviously learning is not very effective or in other words, learning is unsuccessful. As a parent in the class, the teacher must be able to find a teaching technique that fits to the situation and condition of the classroom. There is very important reason why the teacher should be able understanding meaning. Students that are good in understanding meaning will be easier to do examinations than those who are not incapable in understanding meaning.

Using real media simply means using examples of language produced by teachers for some real purpose of their own rather than using language produced and designed solely for the classroom. Anybody who takes into the classroom, a newspaper article, an advertisement, a pop song, a strip cartoon, or even a bus ticket, is using real media. Teachers have always introduced such media into their classrooms. From the explanation above, the writer will conduct a research with the title "The Effect of Real Media on the Students' Ability in Writing Procedure Text of the Eighth Year Students of SMP Swasta Dewantara Putra Sebertung at Academic Year 2018/2019.”

\section{RESEARCH METHOD}

This study was conducted by applying a research or study named experimental research design. There were two groups, namely experimental group and control group. The experimental group was the group which received the treatment by applying real media at the class while the control group did not. It means that this study intends to find out whether there is the effect of real media on the students' ability in writing procedure text of the eighth year students at SMP Swasta Dewantara Putra Sebertung in academic year of 2018/2019. This research was conducted at SMP Swasta Dewantara Putra Sebertung, Jalan Jamin Ginting Kecamatan Bohorok Kabupaten Langkat. The reason for choosing this school was due to the terms of accessibility and collecting the data. And the time of the research was in August 2018. 
The population in this study took the eighth year students at SMP Swasta Dewantara Putra Sebertung. The total population was 70 students in two classes. Each of class consisted of 35 students. All of the populations was as sample. The research focused on the class which was divided into two classes. One class was taught by applying the real media which was called as experimental group, while the other class was not taught by applying real media which was called as control group. This research used a random sampling technique which recommended the writer to make that every member of population had right and chance to be chosen as sample. The random sampling technique could be conducted through lottery and the researcher had no interest or criteria toward the chosen sample.

In conducting this research, the instrument is used to collect the data namely a writing test to collect the data by applying list of clues with its real (authentic) materials according to the topic to facilitate the students in understanding a procedural text. In scoring the test later then, there are several compositions focusing on a list of criteria. The teacher's evaluation on writing almost never concerned with the other parts or criteria of writing, but because this study was conducted by using a number of $\mathbf{1 0}$ questions in multiple choices, so the scoring on the students' ability in writing a procedural text depended on how strictly they answered the questions based on the number of correctness or incorrectness. The maximum score of the test was 100 . If a student could answer 5 items of question, so his score will be multiplied by 100 and then the sum must be divided by 10 .

\section{THE DATA AND DATA ANALYSIS}

In this study, the writer used the data which was gathered from the eighth year students of the 2018/2019 at SMP Swasta Dewantara Putra Sebertung. In addition, a clear description about the students' basic ability (Pre-test) in writing procedural text ability for experimental group that was taught by applying the real media was explained as the writer has calculated the whole scores (1490) and then divided the summary with total sample i.e. 35 students then the mean worth as $\mathbf{4 2 . 5 7}$. Thus it meant that students in this experimental group approximately could answer the question in very low level. A clear description about the students' advanved ability (Post-test) in writing procedural text ability for experimental group that was taught by applying the real media was explained as the writer has calculated the whole scores (2730) and then divided the summary with total sample i.e. 35 students then the mean worth as $\mathbf{7 8}$. Thus it meant that students in this experimental 
group approximately could answer the question in good level. A clear description about the students' basic ability (Pre-test) in writing procedural text ability for control group that was taught by applying no strategy was explained as the writer has calculated the whole scores (1380) and then divided the summary with total sample i.e. 35 students then the mean worth as 39.43. Thus it meant that students in this control group approximately could answer the question in very low level. A clear description about the students' advanced ability (Post-test) in writing procedural text ability for control group that was taught by applying no strategy was explained as the writer has calculated the whole scores (1770) and then divided the summary with total sample i.e. 35 students then the mean worth as 50.57. Thus it meant that students in this control group approximately could answer the question in low level.

To analyze the data, all scores of tests were needed. It was got that coefficient of $t_{\text {counted }}$ was 3.37. Then to find out the effect of the variable $\mathrm{X}$ on $\mathrm{Y}$, the coefficient of $t_{\text {counted }}$ was consulted to the $t_{\text {table }}$ coefficient in Appendix VII with significance level $(\alpha)=0.05$ and degree of freedom $(d f)=68$. So it could be seen that coefficient of $t_{\text {counted }}$ (3.37) was higher than the $t_{\text {table }}$ coefficient (1.66757). This information indicated the hypothesis of the study was accepted that there is the effect of real media on students' ability in writing procedure text of the 2018/2019 eighth year students of SMP Swasta Dewantara Putra Sebertung.

\section{CONCLUSION}

The main objective of this study is to determine whether the real media significantly affects on the students' ability in writing procedure text. The problems that had been identified by the writer are including many of junior high school students have difficulties in understanding the genres of text, they still get lack of vocabularies which makes the students difficult to compose any kinds of text, the procedural texts seem hard for students to comprehend without any practical media, the written language is more complicated than spoken one, and teacher does not have very effective strategy to overcome the students' inability in learning procedural text. From the result of this study the writer concludes that there is a significant effect of real media on students' ability in writing procedure text of the 2018/2019 eighth year students of SMP Swasta Dewantara Putra Sebertung 


\section{REFERENCES}

Gerrot, L. and Wignell, P., Making Sense of Functional Grammar. Cammery: Antipodean Education Enterprises, 2004.

Grondlund, E.N., Measurement and Evaluation in Teaching. New York: McMillan, 2004.

Happer, Catherine and Philo, Greg, The Role of the Media in the Construction of Public Belief and Social Change. (Glasgow University Media Group, University of Glasgow, Glasgow, United Kingdom, 2013.

Murcia, M.C. and Olshtain, E. Discourse and Context in Language Teaching. New York: Cambridge University Press, 2000.

Roestiyah. Model Pembelajaran: Menciptakan Proses Belajar \& Mengajar yang Kreatif dan Efektif Edisi 2. Jakarta: Bumi Aksara, 2017. 